DOI: https://doi.org/10.24113/ijellh.v8i1.10417

\title{
A Lexical Analysis of Words Signifying Happiness in Dickens' \\ Novel Oliver Twist
}

\author{
Zainab Hussein Alwan \\ Department of Religious Tourism- \\ College of Tourist Sciences \\ Karbala University \\ Karbala, Iraq \\ a.karar74@yahoo.com
}

\section{Abstract}

Being a transient state, happiness extends from the highest degree of pleasure to the lowest one. It differs from one person to another. Lexically, happiness can be fulfilled by using certain words that are used to describe this feeling. The existing study tries tofind answers for the subsequent queries:

1. What are the most common words uttered to express happiness in Dickens' novel Oliver Twist?

2. Is there a distinction between happiness and other negative feelings in the texts above?

3. Do they all have the same indications of happiness?

This paper aims at:

1. Examining the semantic aspects of words denoting happiness in Dickens' novel Oliver Twist.

2. Identifying the correlation between happiness and other negative feelings in the text above.

3.Investigating the implied meaning of that words used in this particular novel. 
It is hypothesized that:

\section{DOI: https://doi.org/10.24113/ijellh.v8i1.10417}

1. In Dickens' novel Oliver Twist, there are certain words that carry the meaning ofhappiness.

2.There is no clear-cut distinction between happiness and other negative feelings in Dickens' novel Oliver Twist.

3. It is suggested that each word of happiness has a lexical denotation that makes it exceptional.

After analyzing the data selected, the findings of the investigation validate all the hypotheses above.

\section{Literature Review}

In different periods, many scholars studied Oliver Twist from various perspectives, and most of them focused on the analysis Dickens' common style of irregularity or language translation, while few studied the novel from the perspective of semantics. For instance, Miyata (2011) studied the deviation from the norm in Oliver Twist, Shantikumar Sharma \&Shimreingam (2017)and Lian(2018)examine the degradation of the human relation at the Victorian age. Stefan (2014)figured out the challenges of the translating idiom.

To bridge the semantic gap, this paper deals with happiness, which is a psychological state, in terms of semantics. It intends to further validate that happiness can be expressed linguistically in the above-mentioned novel.

\section{Introduction}

Being a multidimensional experience, happiness is enthroned in people's hearts. It is either a transient state or lasting for a long time. The study attempts to the following questions: 1. Linguistically, what are the words used to express happiness in Dickens' novel Oliver Twist? 2. Is there a clear-cut distinction between happiness and other negative feelings in the texts above? 
DOI: https://doi.org/10.24113/ijellh.v8i1.10417

3.What is the indications of words of happiness?

This paper aims at:

1. Investigating the semantic properties of words of happiness in Dickens' novel Oliver Twist.

2. Showingthe interaction between happiness and other unfavourable feelings in the text above.

3. Determining implications of that words in the text above.

It is hypothesized that:

1. Concerning Dickens' novel Oliver Twist, happiness can be conveyed linguistically.

2.it is expected that happiness has an association with other unwilling senses.

3. It is also suggested that each word of happiness has a lexical meaning that makes it remarkable

The procedures adopted are:

1- Reviewing the concept of happiness and its various denotations.

2- Analyzing some selected texts from Dickens' novel Oliver Twist in terms of using words of happiness.

\section{Definitions of Happiness}

Dating back to the Ancient Greeks, Veenhoven $(1984: 1,17)$ emphasizes that happiness has various indications. Wierzbicka (1992:539) and Lewis et al.(2008:106) agree that happiness is one of the basic positive emotions. Jiménez-Briones and Alba (2008:136) also state that happiness occupies the most salient feeling "within the domain of emotions."

For Waterman (1993: 678), happiness is a subjective experience. Lu (2001:1) sees happiness as a matter of having a peace of mind.

In a broad sense, Veenhoven (2006:3) remarks that happiness is synonymously used with 'quality of life' or 'well-being'. Similarly,Diener et al. (2010:40) point out that happiness means "chance or fortune". 
DOI: https://doi.org/10.24113/ijellh.v8i1.10417

To be seen as a complex process, happiness involves certain steps to be achieved (i.e. it is integration (of identity), fulfillment (of needs) and extension (contrary to alienation) (Schulz-Hageleit, 1979, as cited in (Veenhoven, 1984:1, 17 and Fink, 2013:127)).

Michalos (1980:57) defines happiness as "a lasting, complete and justified satisfaction with life". Likewise, Aaberg(2003:108) assumes that happiness is "the emotion that is excited by the acquisition or expectation of good." They both agree that happiness lasts for a short time.

Contrary to that position,Gumpert (1951) and Hartman (1934), as cited inVeenhoven (1984:1, 17), affirm that happiness is a long-lasting state that is characterized by positive attitude(s).

As a social state, Mihalcea and Liu (2006:3) remark that happiness is a natural condition in human daily life. Lewis et al. (2008:457) also state that happiness can be seen as "sharing positive experiences with others

Hard to be defined, Sillick and Cathcart (2013:494) confirm that happiness " is an elusive construct and difficult to definedue to its inherent subjectivity." Happiness, as Fink (2013:143) concludes, is the cornerstone of life.

\section{Types of Happiness}

Having a positive sense, Janis (2010:1-2) classifies types of happiness as follows:

1- Physical Happiness: it requires the essentials of life such as water, food,air, and shelter.

2- Emotional Happiness: it breads from "feelings of love, belonging, and having a sense of family or community."

3- Mental Happiness: it "includes making good use of one's mental ability to continually improve and grow in his understanding and appreciation of life."

4- Creative Happiness: it arises from doing "one's creative efforts to benefit society and those he loves."

5- Spiritual Happiness: it comes with "the peacefulness of unshakable faith" 


\section{DOI: https://doi.org/10.24113/ijellh.v8i1.10417}

6- Eternal Bliss: it is "a realm of unearthly ecstasy and oneness with all."

\section{Different Perspectives on Happiness}

Being analyzed in different dimensions, happiness includes philosophy, society, psychology, religion, and culture.

According to Veenhoven (1984:3) and Lu (2001:1), happiness is purely a psychological phenomenon. It is a matter of maintaining harmony between oneself and the outside. Atanassova-Trifonova(2011:1) confirms that "happiness is one of the emotions that people experience, express, and identify in others from the very early stages in life."

For Veenhoven (1984:23) and Sillick andCathcart (2015:495), religion is anchored in happiness.

\section{This made several investigators expect that believers are generally more satisfied with their life than non-believers, and fully committed church-members happier than the marginal ones. Some of them also considered differences in happiness between people of different religious denominations.}

Veenhoven (1984:23)

Being a crucial philosophical issue, Wienand (2009:105) emphasizes that happiness is" based on the principle that each person can find his or her own method to reach selfcontentment."

From the social point of view, Veenhoven (2006:23) and Rojas and Ibarra-López (2014:23) agree that happiness is a human interactive state which can be shared with others and it has different forms in various contexts. 
DOI: https://doi.org/10.24113/ijellh.v8i1.10417

Happiness is ordinarily understood as how much one likes the life one lives, or morestrictly, the degree to which one determine one's lifeas-a-wholeoptimistically. Happiness is felt by persons who are insociety and who are living in their circumstance. Consequently, the consideration of happiness necessitates incorporating aperson's context that implies the need for integratinghow people interact with others.(Veenhoven, 2006:23)

Culturally, there is a tight bond between happiness and culture. Uchida et al. (2004:224) point out that "happiness might vary considerably across cultures."

Regardless of age, intelligence and attractiveness, Zimbardo and Weber (1997:372-3) emphasize that there are other factors that affect the concept of happiness such as love, work satisfaction, and personality.

\section{Happiness and Gender}

Happened naturally, happiness is higher in women than in men. Many studies have emphasized that women tend to be happier than men in their adulthood. As they gradually grow up, women become less happy than men (http://ww w.centreforhumanpotential.com.au/blog/happiness-and-gender/).

To be compared with women, it is found that men are happier than women in Brazil and UAE. They are happier with their physical and mental health. On the contrary, women tend to be happier with their religious and spiritual beliefs(http://www.ameinfo.com/183081.html). 
7. Happiness: Linguistically

\section{DOI: https://doi.org/10.24113/ijellh.v8i1.10417}

According to Lu (2001:1) and Radford (2004:31), happiness is a noun of the adjective happy. It is used to denote the meaning of fortunate or lucky, besides the two other meanings:

(2) (In polite formulas) pleased;

(3) (Of language, conduct, suggestion) well-suited to the situation.

Lam (2004:6) points out that "the non-count noun 'happiness' is generic, applied to almost every kind of enjoyment."

Being a typical adjective having all the derivational properties of regular adjectives, Happy, as Lam and Radford assert, has the following derivations:

1- Unhappy (the negative prefix un-)

2- Happier/happiest (comparative/superlative suffixes -er/-est)

3- Happily (the adverbializing suffix -ly)

4- Happiness (the nominalizing suffix -ness)

Alexander (1988:26), Eastwood (2002: 154), Radford (2004:28) and Hudson (2007:213), agree that Happy is an adjective which is used for describing a personal feeling.

From the syntactic point of view, Happy can be used both attributively and predicatively (Bouillon and Viegas, 1999:2)

(1) She is a happy woman. (an attributive adjective )

(2) You seem happy today. (a predicative adjective )

Along with sad, small, wise, healthy and wealthy, Happy, as Chalker and Weiner (1994:328) remark, is one of the qualitative adjectives which "describe quality that someone or something has."

To create a special rhetorical effect, a double negation of not unhappy can cancel the sense of negation and produce an affirmative one (Verhagen, 2005:70).

(3) I am definitely not unhappy with his remarks. 
DOI: https://doi.org/10.24113/ijellh.v8i1.10417

In a similar vein, Kroeger (2005:211) differentiates between sentence negation and morphological negation, in the sense that the former is a negative sentence; whereas the latter is a positive one.

(4) a- Arthur is not happy, is he?

b- Arthur is unhappy, isn't he?

For Greenbaum (1996: 621) and Eastwood (2002: 398), the adjective Happyoccurs with the copular verbs, such as: seem and look.

(5) All lookedhappy.

Concerning its function as a compliment, the adjective happy can be used as Cs=subject complement or Co=object complement (Downing and Locke, 2006:494)

(6) I am happy. (ibid)

(7) I am happy that you are here. (Co relating to a fact) (ibid)

(8) I am happy to see you. (Co relating to a process) (ibid)

(9) I am happy about your success. (Co relating to a circumstance) (ibid)

Alexander (1988:95) states that the formula (possessive adjective +adjective+ self(noun)) is employed to describe (feelings or emotions).

(10) Frankdidn't sound his happy self on the phone this morning. (ibid)

To avoid redundancy and absurdity, one of the restrictions of the word Happy is that it cannot be followed by spatial prepositions (Feigenbaum andKurzon, 2002:121-2).

(11) Mary is happy.

(12) \#Mary is happy in the garden.

Downing and Locke (2006:495) emphasize that the adjective happy is used in "that - clause" (13) I am happy that you are leaving. 
DOI: https://doi.org/10.24113/ijellh.v8i1.10417

Being combined with many prepositions such as: (about \over \at \with), the adjective Happy is endowed with new meanings "to be satisfied and not worried" (Longman of Exams Dictionary,2009:712).

(14) I am happywith the way 1 look.

(15) We are happyabout your exam results.

(16) He was not happy about the proposals.

(17) I am so happy for you.

(18) I am happy to hearfrom you.

(19) Although the happiness and delight of my life lie buried there too, I have not created a coffin of my heart.

For Lam (2004:3), the adjective Happy has divergence structures of:

1- Equality: (18) He is as happy a tutor as my brother.

2- Inequality: (19) I am not as/so happy as he is.

3- Comparative: (20) You will make me happier than I can tell you.

4-Superlative:(21) Now began the happiest phase of my life.

Idiomatically, the adjective Happy can be chained with some words in order to denote additional meanings (Greenbaum, 1996: 426, Azar et al., 2003:117, Lam, 2004:6 and Longman of Exams Dictionary, 2009:712).

(22) I've never felthappier in my life.

(23) I loved her and thought I could make her happy.

(24) I will be so happyto see you.

(25) I am so happyfor you.

(26) She is anattractiveschoolgirl with a happy disposition.

(27) He is as happy as a clam!

(28) Happy Christmas. 
DOI: https://doi.org/10.24113/ijellh.v8i1.10417

According to Downing and Locke (2006:506), the adjective Happy may have intensifiers to make the meaning more strong.

(26) He lives all alone but seems pretty happy.

The adjective Happy, as Radford (2004:60) states, can be alternatively used to avoid redundancy.

(27) a. How does she feel?

b.Happy.

Similarly, Panther et al. (2009:222) highlight that the adjective Happy can be ellipted when it is recoverable from the context.

(28) I'm happy if you are (happy).

Panther et al. resume their explanation saying that the adjective Happy is combined with the definite article "the" to indicate "generic reference".

(29) The happy live longer.

8. Additional Uses of the Adjective "Happy"

Formally, informally, and in literature, as cited in Brinton (1984: 228), Quirk et al. (1985:1114), Greenbaum (1996:54,426,521), Eastwood (2002: 164), Lam (2004:6), Swan (2005: 240) and Longman of Exams Dictionary(2009: 712), the adjective Happy is widely common and it has extra purposes and they can be summarized as follows:

1-Politeness:(34) I'm happy to answer all your questions.

(30)I'm happy to meet you.

2- Conventional form of wishes: (30)Many happy returns.

3- Greetings for Special occasions: (31) Happy Birthday.

4-Exclamations:(32)How happy I am to see you!

5-Praise:(33)I'm very happy with your work. 
DOI: https://doi.org/10.24113/ijellh.v8i1.10417

6-Making logical conclusions:(29)She must be happy.

7-Willingness:(35)I am happy to help you.

8-Literal use:(35)The film has a happy ending.

9- The standard seasonal greetings: (28) Happy Christmas.

10-Parallelism:(35)Although the happiness and delight of my life lie buried there too, I have not made a coffin of my heart.

11-Compassionate Attitude:(35)I am happy to see you again.

(35)I am happy to tell you about my academic performance.

12-Formal use:(35) His choice of words was not a very happy one.

13-Informal use:(35) Happy hour runs from 4:00 to 8:00 pm.

9. Words Denoting Happiness

Lam (2009:165) enumerates a number of words that convey the feeling of great pleasure as follows:

9.1 AdjectivesDenoting Happiness

\subsection{1 'Delighted'}

Delighted is "an adjective having the feature of feeling huge pleasure about something good that has occurred. " With a difference in degree of feeling happiness, the adjective delight can be used synonymously with 'happy', 'glad' and 'pleased'.

1- I am delighted to hear of your success.

\subsection{2 'Elated'}

To show the greatest feeling of happiness and pride, elated is to be excited. 
DOI: https://doi.org/10.24113/ijellh.v8i1.10417

2- Jeremy felt elated at this sudden and unexpected success.

\subsection{3 'Jubilant'}

Jubilant is also an adjective that denotes the feeling of being very happy because of achieving something or happening something bad to someone.

3- The climbers were jubilant after reaching the top of Everest.

\subsection{NounsDenoting Happiness}

\subsection{1 'Bliss'}

Bliss is a noun that formulates a perfect happiness.

4- If there's another world, he lives in bliss.

\subsection{2 'Ecstasy'}

Being in an extreme happiness, ecstasy is another noun that indicates the feeling of pleasure.

5- This is the very ecstasy of love.

\subsection{3 'Glee'}

To be a delight at another's foolishness, glee"suggests spiteful pleasure such as that experienced at another's bad fortune."

6-He laughed with glee when he learned of his opponent's defeat.

\subsection{3 'Joy'}

Joy is a noun that has the meaning of bringing "pleasure or success".

7- My child is a great joy to me.

8-I tried to get her on the phone, but I didn't have any joy.

9.3 Verbs of Happiness

\section{3..1 'Exult'}


DOI: https://doi.org/10.24113/ijellh.v8i1.10417

Feeling pleasure because of happening something bad to someone, exult is a verb of happiness which "usually takes the complementation types of prepositional phrases with at, in and over.,

9-He was exultant. "They lost the game", he shouted.

\subsection{2 'Rejoice’}

Rejoice "is a transitive verb but with no passive form." being widely common in religion, the verb rejoice conveys the meaning of having unmanageable happiness.

10- They all rejoiced that the war was over.

\subsection{3 'Please'}

Jiménez-Briones and Alba (2008:136) state that to please somebody is "to cause him feeling happiness."

11- The song pleases me.

\subsection{4 'Gratify'}

Making someone feeling happiness is to gratify him.

12- His praise gratified me a lot.

\subsection{5 'Satisfy'}

Satisfy is another verb of happiness which means "causing somebody to feel satisfaction." 12- The song pleases me.

\subsection{6 'Fulfill'}

According to Jiménez-Briones and Alba (2008:138), fulfill is to cause somebody to feel fulfilled. 
DOI: https://doi.org/10.24113/ijellh.v8i1.10417

I don't feel my present way of life fulfilled me.

\subsection{7 'Cheer'}

Cheer is to make someone feeling happy and confident.

\subsection{8 'Hearten'}

Enthusiastically, Jiménez-Briones and Alba (2008:138) emphasize that hearten requires causing happiness in an encouraging way.

Something that comforts or gladdensis a sudden feeling of excitement

\subsection{9 'Thrill'}

To thrill means to be happy and excited.

\subsubsection{0 'Exhilarate'}

For emphasis, Jiménez-Briones and Alba (2008:138) claim that the verb exhilarate signifies feeling happiness in a refreshing way.

\subsubsection{1 'Leap'}

The verbs leap expresses the feeling of great happiness (Janis, 2010:30).

- His disappointment had turned to joy and he leaped in the air, relived the Bookman had escaped.

\subsubsection{2 'Roll'}

In an uncontrolled way, Janis (2010:30) mentions that roll is another verb of happiness.

- A teller of tall tales has been brought in to help would-be vicars keep the congregation rolling in the aisles. 


\section{DOI: https://doi.org/10.24113/ijellh.v8i1.10417}

Besides, Lam (2009:171-2) remarks that there are some idioms denoting happiness 'walk on air', 'in seventh heaven', 'on cloud nine', 'on top of the world', 'over the moon' and 'thrilled to bits'.

1- 'Walk on air' is to be very happy because something great has happened.

-She's been walking on air ever since she met Julia.

2-'In seventh heaven' denotes " the property of feeling very happy about something or enjoying oneself immensely."'

- Gloria was in seventh heaven as she wandered around the shops knowing she could buy whatever she liked.

3-'On cloud nine', describes ' "the property of feeling extremely happy, usually for those who are in love',

-He was on cloud nine after winning the competition

10. Data and Analysis

Relying on the foregoing discussion, it is worthy to mention that the model adopted for analyzing the following selected verses is developed on the basis of other models, such asLam (2003), Jiménez-Briones and Alba (2008), Huong andLam(2008), Lam (2009) and Eva (2013) who numerate some words that denote happiness directly or indirectly, in addition to the observations made by the researcher herself. The eclectic model used for the analysis of the present study illustrates the semantic level of happiness and its synonyms. Text-1 -

'If they knew how happy I am, they would be pleased, I am sure.' 
DOI: https://doi.org/10.24113/ijellh.v8i1.10417

Being something rare and missing in his life, Oliver touches the senses of happiness from one time to another. The presence of kind people ensures living under the shadow of security and tranquility.The word pleased indicates the great tenderness that Oliver receives from different people at that age which is marked by lack of purity, innocence, and virtuous aspects.

Text- 2 -

I have got a friend that I think can gratify your darling wish, and put you in the right way, where you can take whatever department of the business you think will suit you best at first, and be taught all the others.'

In this particular text, the word gratify symbolizes the superficial happiness which lasts for a short time. The illusive sight of happiness which is tied up with deception is figured out by Fagin who wants to persuade Noah of his strategic plans. Dehumanization and utilizing children are signs of the Victorian age.

\section{Text-3 -}

'I heard the doctor tell them I was dying,' replied the child with a faint smile. 'I am very glad to see you, dear; but don't stop, don't stop!' 'Yes, yes, I will say goodbye to you,' replied Oliver. 'I shall see you again, Dick. I know I shall! You will be well and happy!'

With an optimistic sense, Oliver hopes that his friend may be well. He comforts him by saying that there is still an opportunity to be recovered. Oliver wishes that all his hopes come true. These inspiring words show his tenderness and his focus on others' needs.

Oliver shares others' suffering and sympathizing with them. He has a soft heart in a cruel world. Handling the present moments with confidence, Oliver believes that there is no hopeless situation. 
Text- 4 -

\section{DOI: https://doi.org/10.24113/ijellh.v8i1.10417}

'I rather think I had a damp napkin at dinner-time yesterday, but never mind that. How do you feel, my dear?' 'Very happy, sir,' replied Oliver. 'And very grateful indeed, sir, for your goodness to me.'

Compassionately, Oliver is happy and thankful for Mr. Brownlow who is the only source of hope and pleasure in his life. Oliver, in this scene, is in high spirit. He acknowledges that Mr. Brownlow represents the face of goodness and relief for him. The support he receives from Mr. Brownlow encourages him to spread happiness to others.

Oliver is mentally and emotionally happy. Feeling satisfied with the people around, he practices actual happiness. This sort of happiness appears in one's face.

\section{Text- 5 -}

I hope not,' rejoined the old gentleman. 'I do not think you ever will. I have been deceived, before, in the objects whom I have endeavored to benefit; but I feel strongly disposed to trust you, nevertheless; and I am more interested in your behalf than I can well account for, even to myself.

The persons on whom I have bestowed my dearest love, lie deep in their graves; but, although the happiness and delight of my life lie buried there too, I have not made a coffin

In a world full of cruelty, it is clear that uttering the words happiness and delight give rise for hope and satisfaction. Mr. Brownlow has inherent good traits. He is a kind and caring person whom Oliver likes. These words of happiness signify the meaning of pleasure which is implied in one's heart. Despite all hardship, one should be happy and optimistic.

Text-6

'Has he, ma'am?' cried Oliver, his face brightening with pleasure. 'I don't know what I shall do for joy when I see their kind faces once again!' In a short time, Oliver was sufficiently recovered to undergo 
DOI: https://doi.org/10.24113/ijellh.v8i1.10417

the fatigue of this expedition. One morning he and Mr. Losberne set out, accordingly, in a little carriage which belonged to Mrs. Maylie

To be a source of pleasure, Oliver makes use of the word joy to reflect his inner feeling of happiness. Dickens, here, tackles the way of behaving with people in order to attain the everlasting happiness which is compatible with safety and peace of mind. Faithfully, Oliver is in debt to those who help him in one way or another and try to alleviate his suffering. Such nice people inspire him and they are too concerned with him.

Text-7 -

'I am so fond of them, Mr. Bumble, you can't think,' replied the matron. 'They're SO happy,

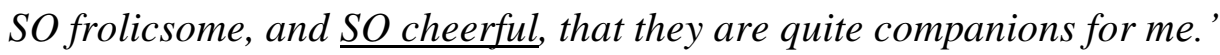

Mrs. Corney looks like her age in her treatment. She lacks all traits of humanism such as mercy, kindness, sympathy etc. She contradicts herself by herself once uttering this word cheerful. The representation of Victorian animals with human characteristics are very common.

Ironically, Dickens, here, criticizes the Victorian age sating that people of that time are deprived of their human nature. He tries to mirror the social surroundings through the transference of human features to non-human living creatures. Depicting the carelessness and violence of the Victorian age, animals, at that time, have acquired most human emotions such as sympathy, happiness etc. Such qualities are of value for human's nature.

Text-8 -

'Gadso!' said the undertaker: taking Mr. Bumble by the gilt-edged lapel of his official coat; 'that's just the very thing I wanted to speak to you about.'

In this scene, Mr. Sowerberry, the coffin-maker,uttersGadso which is an interjection used to express happiness that is compatible with excitement. For him, exploitation children are the root of his pleasure. After asking for more food which is considered as a threat to the 
DOI: https://doi.org/10.24113/ijellh.v8i1.10417

corrupted world, Oliver has been sent with Mr. Sowerberry. Actually, Oliver is shuffled in misery. Mr. Sowerberry has got what he is hoping for, a child who can work with him. Feeling happiness at the expense of others' suffering is so common at that time.

Conclusion

In spite of the miserable atmosphere, it is obvious that words denoting well-being are widely used in this particular novel. This can be ascribed to the author's ultimate goal of escaping the present situation.The word "happy" is the most common word of happiness that are employed in this novel. This can be attributed to the comprehensiveness of this word,its aesthetic dimension and the richness of having this feeling.This validates the hypothesis which reads "It is suggested that each word of happiness has a lexical denotation that makes it exceptional."

In the light of the data selected, it is clear that people practice happiness differently. This verifies the hypotheses which say "happiness differs from one person to another and from one situation to another."Words of happiness are not pure ones, they are in the middle of the happiness-sadness continuum. This validates the hypothesis which states that "There is no clear-cut distinction between happiness and other negative feelings in Dickens' novel Oliver Twist." 
DOI: https://doi.org/10.24113/ijellh.v8i1.10417

\section{Bibliography}

Aaberg, Dennis G.(2003). Topic Bible Studies Addressing Everyday Problems and Questions. (https://books.google.iq/books?isbn=1591603986)

Alexander, L.G. (1988). Longman English Grammar. New York:Longman Inc.

Atanassova-Trifonova,Maria. (2011). Patterns of appraisal of happiness and fear different perspective of adolescents and young adults. In:

Kokinov, B., Karmiloff-Smith, A., Nersessian, N. J. (eds.)European Perspectives on Cognitive Science.

Azar, B. Schrampfer; Matthies, Barbara F., and Hartle, Shelley(2003) .Fundamentals of English Grammar $\underline{\left(3^{\text {rd }} e d\right) . ~ N e w ~ Y o r k: ~ P e a r s o n ~ E S L . ~}$

Bouillon,Pierrette, and Viegas,Evelyne. (1999).The Description of Adjectives for Natural Language Processing: Theoretical and Applied Perspectives. Atelier Th'ematique TALN.

Diener, Ed; Kahneman,Daniel andHelliwell,John. (eds.) (2010).

InternationalDifferences in Well-Being. Oxford: Oxford University Press.

Downing, Angela, and Philip, Locke. (2006) English Grammar: A University Course (2 $\left.{ }^{\text {nded }}\right)$. Abingdon: Routledge.

Eastwood, John. (2002). Oxford Guide to English Grammar. Oxford: Oxford University Press. Eva, Leláková (2013). The Role of a Common Semantic Feature and a Diagnostic Frame in the Process of the Linguistic Data Collection.In Sučasnidoslidžennja $\mathrm{z}$ inozemnojifilologiji : zbirnyknaukovych prac.

Fink,Charles K. (2013). Better to Be a Renunciant Buddhism, Happiness, and the Good Life. Journal of Philosophy of Life Vol.3, No.2 pp.127-44.

Feigenbaum,Susanne and Kurzon,Dennis (eds.) (2002).Prepositions in their Syntactic, Semantic and Pragmatic Context. Amsterdam: John Benjamins Publishing Company 
DOI: https://doi.org/10.24113/ijellh.v8i1.10417

Greenbaum, Sidney. (1996). The Oxford English Grammar.Oxford: Oxford University Press. Hudson, Richard. (2007). Language Networks: The New Word Grammar. Oxford: Oxford. University Press.

Huong, Nguyen ThiThanh and Lam,Nguyen Thi Van (2008). Grammatical and Semantic Features of some Adjectives Denoting Happiness - The Feeling of Pleasure.VNU Journal of Science, Foreign Languages 24, pp. 157-66.

Janis, Sharon. (2010). Secrets of Spiritual Happiness. <http://www.spiritual-happiness.com> Jiménez-Briones, Rocio and Alba, Pérez Cabello de (2008). Lexical Representation within the Lexical Constructional Model: An Analysis of Verbs of Happiness and Happening. RESLA 21, pp. 129-46.

Kroeger, Paul R. (2005). Analyzing Grammar An Introduction. Cambridge: Cambridge University Press.

Lam, Nguyen Thi Van (2004). Grammatical and Semantic Features of the Word Denoting Happiness 'Happy'.<http://www.tuninst.net/ENGLISH/MaLam01.htm>

Nguyen Thi Van (2009). Grammatical and Semantic Features of some English Words and Idioms Denoting Happiness - The Feeling of Great Pleasure.VNU Journal of Science, Foreign Languages 25,pp. 165-73.

Lewis, Michael; Haviland-Jones, Jeannette M., andBarrett, Lisa Feldman. (2008). HANDBOOK OF EMOTIONS (3 ${ }^{\text {rd }}$ ed.) New York: The Guilford Press.

Longman of Exams Dictionary. (2009). England: Pearson Education Limited.

Lu, Luo (2001).Understanding happiness: A Look into the Chinese Folk Psychology.Journal of Happiness Studies, 2, pp.407-32.

Miyata, Masanori. (2011 ).Types of Linguistic Deviation in Oliver Twist. http://www.dickens.jp/archive/ot/ot-miyata.pdf 
DOI: https://doi.org/10.24113/ijellh.v8i1.10417

Michalos, Alex. (1980).Analysis of Happiness. Social Indicators Research. Volume 8, Issue 4, pp. 507-10.

Mihalcea,Rada and Liu,Hugo. (2006). A Corpus-based Approach to Finding Happiness.In Proceedings of the American Association for Artificial Intelligence Spring Symposium on Computational Approaches to Weblogs.

Lian, Min.(2018). Analysis of Dickens' Critique and Humanity Spirit in Oliver Twist Based on the Appraisal Theory. Theory and Practice in Language Studies, Vol. 8, No. 8, pp. 1050-1054.

Panther, Klaus-Uwe; Thornburg, Linda L., and Barcelona, Antonio (eds.) (2009). Metonymy and Metaphor in Grammar. Amsterdam: John Benjamins Publishing Company.

Quirk, Randolph; Greenbaum, Sidney; Leech, Geoffery, and Svartvik, Jan (1985). A Comprehensive Grammar of the English Language. London: Longman Group Ltd.

Radford, A. (2004) Minimalist Syntax: Exploring the Structure of English. Cambridge: Cambridge University Press.

Rojas, Mariano and Ibarra-López, Ignacio (2014). Happiness and Human Relations: The Role of Materialistic Values. An ABM Illustration. International Journal of Artificial Intelligence and Interactive Multimedia, Vol. 2, No. 5.

Sandström, Karin (2006). When Motion Becomes Emotion: A Study of Emotion Metaphors Derived from Motion Verbs. (http://epuble.ltu.se/1402-1552/2006/022/LTU-DUPP06022.SE.pdf.)

Shantikumar Sharma, K. andShimreingam, H.(2017).Human Relationshipsin Charles Dickens' Oliver Twist. https://ashvamegh.net/human-relationship-in-charles-dickens-oliver$\underline{\text { twist/ }}$ 
DOI: https://doi.org/10.24113/ijellh.v8i1.10417

Sillicka, Warren J., and Cathcarta, Stuart (2013). The Relationship between Religious Orientation and Happiness: The Mediating Role of Purpose in Life. (www.tandfonline.com/doi/pdf/10.1080/13674676.2013.852165)

Stefan,Mihaela-Raluca. (2014). Translating somatic verbal idioms from Oliver Twist. http://www.diacronia.ro/ro/indexing/details/V1789/pdf

Swan, Michael. (1995). Basic English Usage. Oxford: Oxford University Press. Uchida,Yukiko; Norasakkunkit, Vinai and Kitayama,Shinobu (2004).

Cultural Constructions of Happiness: Theory and Empirical Evidence. Journal of Happiness Studies 5: 223-239.

Veenhoven, Ruut (1984).CONDITIONS OF HAPPINESS.

(https://personal.eur.nl/veenhoven/Pub1980s/84a-full.pdf)

Veenhoven, Ruut (2006). How do we assess how happy we are? Paper presented at the conference on 'New Directions in the Study of

Happiness: United States and International Perspectives', University of Notre Dame, USA, October 22-24.

Verhagen, Arie. (2005). Constructions of Intersubjectivity. Discourse, Syntax, and Cognition. Oxford: Oxford University Press

Waterman, Alan S.( 1993)Two Conceptions of Happiness: Contrasts of Personal Expressiveness (Eudaimonia) and Hedonic Enjoyment. Journal of Personality and Social Psychology,Vol.64.No.4.pp.678-91.

Wienand, Isabelle. Discourses and Happiness. Ethical Perspectives Vol.16, Issue: 1, pp.: 10328.

Wierzbicka, Anna. (1992). Defining Emotion Concepts. Cognitive Science, 16, 539-581.

Zimbardo, P. G., and Weber, A.L. (1997). Psychology. New York: Longman Press. 